\title{
CIVILPROCESUĀLĀS AIZSARDZĪBAS PRET VARDARBĪBU TIESİBU NORMU PIEMĒROŠANAS PROBLEMĀTIKA UN AKTUĀLIE GROZĪJUMI NORMATİVAJĀ REGULĒJUMĀ
}

\section{CHALLENGES AND RECENT REGULATORY AMENDMENTS CONCERNING APPLICATION OF LEGAL PROVISIONS FOR CIVIL PROCEDURAL PROTECTION AGAINST VIOLENCE}

\author{
Inese Libina-Egnere, Dr. iur. \\ Latvijas Universitātes Juridiskās fakultātes \\ Civiltiesisko zinātṇu katedras docente
}

\begin{abstract}
Summary
The article examines introduction of a civil procedural mechanism - temporary protection against violence - in the legislation of Latvia in 2014, and the basic rules for its application. Additionally, the article examines other significant amendments made during the introduction of the complex regulation on temporary protection against violence. Continuous legislative improvements are important, given that an efficient and fair regulatory and legislative framework is a key factor in combatting violence. Over the past year, multiple issues concerning the application of the regulation on temporary protection against violence have emerged; as a result, several improvements have been made to the legal framework of this mechanism.
\end{abstract}

Atslēgvārdi: vardarbība, pagaidu aizsardzība pret vardarbību, sociālā rehabilitācija.

Keywords: violence, temporary protection against violence, social rehabilitation.

\section{Ievads}

Latvijā vardarbība, īpaši vardarbība gimenē, arvien ir nopietna problēma, kuras apkarošanai ir nepieciešamas ne vien izmaiņas sabiedrïbas attieksmē, bet arī efektīvs tiesiskais regulējums cietušo tiesību aizsardzībai. Latvijas Valsts prezidents Egils Levits ir sacijis, "ka vardarbỉba ir kauna traips sabiedrībai un ir nepieciešams plašs pasākumu kopums, lai to izskaustu"1.

1 "Dod pieci!" aicinās valsts līmenī sakārtot atbalstu cinnai ar vardarbību ǵimenē. Pieejams: https://www. lsm.lv/raksts/zinas/latvija/dod-pieci-aicinas-valsts-limeni-sakartot-atbalstu-cinai-ar-vardarbibu-gimene.a386619/ [aplūkots 09.03.2021.]. 
Latvijas Republikas Saeima 2014. gada 13. februārī pieņēma grozījumus² Civilprocesa likumā ${ }^{3}$, ar kuriem tika ieviests jauns institūts - pagaidu aizsardzība pret vardarbību. Šie grozījumi bija nepieciešami, lai pielāgotu Latvijas tiesisko regulējumu Eiropas Parlamenta un Padomes Regulai (ES) Nr. 606/2013 par aizsardzības pasākumu savstarpēju atzī̌̌anu civillietās ${ }^{4}$. Likumdevēja mērḳis bija arī nacionālajā līmenī nodrošināt tādu mehānismu, kas efektīvi ḷautu piemērot un īstenot nepieciešamos aizsardzības pasākumus pret vardarbību civillietās. ${ }^{5}$ Tādējādi jau kopš grozijumu Civilprocesa likumā un citos likumos spēkā stāšanās 2014. gada 31. martā regulējums par pagaidu aizsardzību pret vardarbību paredz vienotu mehānismu, lai personu, pret kuru ir vērsta vardarbība, būtu iespējams aizsargāt ar civiltiesiskiem lïdzekliem.

Saskaṇā ar Tieslietu ministrijas Tiesu darba datu portālā pieejamo informāciju kopumā 2020. gadā pirmās instances tiesās iesniegti nedaudz vairāk nekā 1100 pieteikumi par pagaidu aizsardzību pret vardarbību, no tiem 875 apmierināti dal̦eji vai pilnībā. Tas pierāda, ka vardarbība gimenē joprojām ir aktuāla problēma, tāpēc īpaši nozīmīga ir normatīvā regulējuma pastāvīga uzlabošana, lai to padarìtu arvien efektīvāku un taisnīgāku. Pēdējā gada laikā ir veikti nozīmīgi uzlabojumi pagaidu aizsardzības pret vardarbību tiesiskajā kārtībā.

\section{Pagaidu aizsardzỉbas pret vardarbibu regulējums}

Starptautiski pazīstams, taču Latvijā pirms tam nebijis regulējums - pagaidu aizsardzība pret vardarbību - tika ieviests Civilprocesa likumā pirms 7 gadiem, izveidojot jaunu 30. nodaļu ${ }^{5}$. Toreiz tika veikti būtiski grozijumi arī citos liku$\operatorname{mos}^{7}$, tādējādi veidojot saskaņotu mehānismu, kā vērsties pret vardarbību gimenē vai starp personām, kuras ir vai ir bijušas tuvās savstarpējās attiecībās. Ieviešot jauno risinājumu, normatīvo aktu izmaiņas stājās spēkā 2014. gada 31. martā. Grozījumi Civilprocesa likumā, ieviešot pagaidu aizsardzības pret vardarbību institūtu, tiek uzskatīti par nozīmīgākajām izmaiṇām grozījumu pakotnē. Taču, lai pilnīgāk izprastu, kā kopumā šis regulējums darbojas, turpmāk tiks aplūkotas ne tikai Civilprocesa likuma izmaiņas, bet arī citas būtiskas izmaiņas, kas stājās spēkā līdz ar pagaidu aizsardzības pret vardarbību ieviešanu.

Ar grozijumiem Civilprocesa likumā tika ieviests jauns civiltiesisks aizsardzỉbas līdzeklis - pagaidu aizsardzỉba pret vardarbỉbu, kuru tiesa vai tiesnesis, pien̦emot lēmumu, var piemērot vardarbīgajai personai, ar kuru cietušais ir vai ir bijis tuvās attiecībās, ja pret cietušo ir vērsta jebkāda fiziska, seksuāla, psihologiska vai ekonomiska vardarbība vai vardarbīga kontrole. ${ }^{8}$ Lai aizsargātu cietušo no

${ }^{2}$ Grozijumi Civilprocesa likumā: LV likums. Pieṇemts: 13.02.2014. [09.03.2021. red.].

${ }^{3}$ Civilprocesa likums: LV likums. Pieņemts: 14.10.1998. [09.03.2021. red.].

${ }^{4}$ Eiropas Parlamenta un Padomes Regula (ES) Nr. 606/2013 par aizsardzības pasākumu savstarpēju atzī̌sanu civillietās. Pieņemta 12.06.2013. [09.03.2021. red.].

${ }^{5}$ Likumprojekta "Grozījumi Civilprocesa likumā" anotācija. Pieejams: http://titania.saeima.lv/LIVS11/SaeimaLIVS11.nsf/0/7B8AEA1CC9C8588EC2257B35002E8BCE?OpenDocument [aplūkots 09.03.2021.].

${ }_{6}$ Tiesu darba datu portāls. Pieejams: https://dati.ta.gov.lv/MicroStrategy/asp/Main.aspx [aplūkots 09.03.2021.].

7 Piemēram, grozījumi likumā "Par policiju" (pieņemti 06.03.2014.), grozījumi Krimināllikumā (pieņemti 20.03.2014.) u. c.

${ }^{8}$ Civilprocesa likuma $250 .{ }^{44}$ pants, $250 .{ }^{45}$ panta pirmā un otrā daḷa. 
turpmāka vardarbības apdraudējuma, tiesnesis vai tiesa lēmumā var noteikt vienu vai vairākus ierobežojumus vardarbīgajai personai. ${ }^{9}$

Pastāvot vardarbībai vai tās draudiem, personai ir dota iespēja tiesas ceḷā samērā ātri panākt tās personisko tiesību aizsardzību - pieteikumu tiesa vai tiesnesis izlemj ne vēlāk kā nākamajā darbdienā pēc pieteikuma saṇemšanas, izṇēmuma gadỉjumos - 20 dienu laikā. ${ }^{10}$ Turklāt personas vēršanos tiesā atvieglo arī veidlapas ${ }^{11}$, kuras izmantojamas pieteikuma aizpildī̌̌anai.

Personas vēršanos tiesā atvieglo arī izṇēmums no sacīkstes principa izrietošās vispārējās civilprocesuālās prasības prasīājam pamatot savu prasījumu tiesai ar atbilstošiem pierādījumiem. Proti, lietās par pagaidu aizsardzību pret vardarbību lietas dalībnieks ar apliecinājumu apstiprina pieteikumā norādītos lietā nozīmīgos apstākḷus vai tiesas sēdē sniegtos paskaidrojumus. ${ }^{12}$ Tātad, ja citu pierādījumu nav vai tie nav pietiekami, tiesa vai tiesnesis var apmierināt pieteikumu, ņemot vērā ziṇas, kuru patiesumu ir apliecinājis cietušais. Šāds regulējums lielā mērā balstās uz pieteicēja godaprātu, taču, n,emot vērā, ka vardarbībā cietušajam objektīvi bieži vien kādu apstākḷu dēḷ var nebūt iespējas savu pieteikumu pamatot ar pierādījumiem, šāds regulējums tomēr ir ḷoti nepieciešams. Turklāt tas, protams, nenozīmē, ka pieteicējs var sniegt nepatiesas ziņas, jo atbildību par apzināti nepatiesu paskaidrojumu vai pieteikuma sniegšanu tiesai paredz Krimināllikuma ${ }^{13}$ 300. pants, kas ir l̦oti nopietns prevencijas līdzeklis.

Būtiski, ka persona var iesniegt šādu pieteikumu ne tikai tad, ja prasība (piemēram, par laulỉbas šḳiršanu) jau ir celta. Izskatīt jautājumu par pagaidu aizsardzību pret vardarbību piel̦aujams jebkurā procesa stadijā, kā arī pirms prasības celšanas tiesā. ${ }^{14}$ Turklāt l̦oti svarīgi ir atzīmēt, ka tiesa vai tiesnesis lēmumu par pagaidu aizsardzību pret vardarbību var pieņemt gan pēc pašas cietušās personas motivēta pieteikuma, gan arī pēc pieteikuma, kas iesniegts ar policijas starpniecību. ${ }^{15}$ Saistībā ar šo iespēju ir jāmin, ka ar 2014. gada grozījumiem likumā "Par policiju" policijai tika piešķirtas tiesības rīkoties personas tiesību aizsardzībai steidzamās apdraudējuma situācijās un pieṇemt lēmumu par vardarbīgās personas nošḳiršanu no cietušā. ${ }^{16}$ Taču, tā kā lēmums par nošķiršanu ir īslaicīgs risinājums ar salīdzinoši ìsu darbības termiṇu (līdz 8 dienām), cietusī persona ar policijas starpniecỉbu uzreiz var iesniegt pieteikumu par pagaidu aizsardzỉbu pret vardarbību. ${ }^{17}$

2020. gada 1. augustā stājās spēkā samērā būtiskas izmaiṇas ${ }^{18}$, kas paredz, ka policistiem ir pienākums ikvienā izsaukumā, kura laikā tiek konstatēts vardarbības draudu risks, sagatavot ziņojumu par notikumu, ar to informējot pašvaldības sociālo dienestu, lai nodrošinātu efektīvu iesaistīto institūciju sadarbību

\footnotetext{
${ }^{9}$ Civilprocesa likuma $250 .{ }^{47}$ pants un turpmākie panti.

10 Civilprocesa likuma $250 .{ }^{58}$ panta pirmā un otrā daḷa.

11 Kārtība, kādā novērš vardarbības draudus un nodrošina pagaidu aizsardzību pret vardarbību (sk. 1. un 3. pielikumu): Ministru kabineta noteikumi Nr. 161. Pieņemti: 25.03.2014. [09.03.2021. red.].

12 Civilprocesa $250 .{ }^{57}$ panta pirmā un otrā dal̦a.

13 Krimināllikums: LV likums. Pieņemts: 17.06.1998. [09.03.2021. red.].

${ }^{14}$ Civilprocesa likuma $250 .{ }^{45}$ panta trešā dal̦a, $250 .{ }^{55}$ panta pirmā dal̦a.

15 Civilprocesa likuma $250 .{ }^{45}$ panta pirmā daḷa un $250 .{ }^{56}$ panta pirmā daḷa.

${ }^{16}$ Likuma "Par policiju" 12. panta pirmās dal̦as $10 .{ }^{1}$ punkts, $12 .{ }^{1}$ pants.

17 Civilprocesa $250 .{ }^{56}$ panta pirmā daḷa, likuma "Par policiju” $12 .{ }^{1}$ panta sestā daḷa.

18 Grozījumi Ministru kabineta noteikumos Nr. 161 "Kārtība, kādā novērš vardarbības draudus un nodrošina pagaidu aizsardzību pret vardarbību”: Ministru kabineta noteikumi Nr. 462. Pieņemti: 28.07.2020. [09.03.2021. red.].
} 
vardarbības gémenē novēršanai. ${ }^{19}$ Pirms šìm izmaiṇām ziṇojuma sastādīšana un nodošana tālāk citām institūcijām nebija obligāta prakse visā valsts teritorijā. ${ }^{20}$

Policijas loma kompleksajā personas tiesību aizsardzības regulējumā vardarbības situācijās ir būtiska arī tiesas lēmuma par pagaidu aizsardzību pret vardarbību izpildes kontrolē, kuru veic Valsts policija. Par l̦aunprātīgu tiesas lēmuma par pagaidu aizsardzību pret vardarbību nepildīšanu ir paredzēta kriminālatbildība Krimināllikuma $168 .{ }^{1}$ pantā, līdz ar to, ja tiesas lēmums tiek pārkāpts, policija ir tiesīga attiecīgi rīkoties un uzsākt kriminālprocesu. Kamēr vien lēmums ir spēkā un pagaidu aizsardzība pret vardarbību nav atcelta, cietušās personas tiesības joprojām tiek efektīvi aizsargātas, jo turpina darboties tiesas noteiktie aizsardzības līdzekḷi un par to l̦aunprātīgu pārkāpšanu ir paredzēta kriminālatbildība. ${ }^{21}$

\section{Pieteikuma par pagaidu aizsardzību pret vardarbỉbu iesniegšanas vieta (piekritība)}

2020. gada septembrī Latvijas medijos tika publicēts Baltijas pētnieciskās žurnālistikas centra Re:Baltica raksts, kurā tika aktualizēta problemātika par vardarbību gimenē Latvijā. Šajā rakstā tika analizēts gadījums, kad sieviete, glābjoties no varmākas kopā ar nepilngadīgu bērnu, bija radusi patvērumu ārpus vardarbības nodarījuma vietas un savas dzìvesvietas citā pilsētā - Rīgā. Lai mazinātu iespēju tikt atpazìtai, persona pat mainīja savu ārējo izskatu. N̦emot vērā, ka faktiski persona atradās Rīgā, pieteikumu par pagaidu aizsardzību pret vardarbību viṇa vēlējās iesniegt tiesā Rīgā. Taču tiesa pieteikumu noraidỉja. Pēc minētajiem notikumiem personas vīrs atriebības nolūkā nogalināja abu meitu. ${ }^{22}$

Šì situācija izgaismoja pieteikuma par pagaidu aizsardzību pret vardarbību iesniegšanas vietas problemātiku. Tobrīd spēkā esošais regulējums ${ }^{23}$ noteica, ka pieteikumu par pagaidu aizsardzību pret vardarbību pirms prasības celšanas iesniedz tiesai pēc aizskāruma nodarīšanas vietas. Tiesību norma vēsturiski tika pieņemta ar mērḳi, lai pieteikums tiktu iesniegts tiesā, kura ir pieteicējam ērtāk pieejama, prezumējot, ka vardarbība gimenes konfliktos tiek īstenota tur, kur pieteicējs arī faktiski uzturas un dzīvo. ${ }^{24}$ Taču, kā to apliecināja praksē izveidojusies situācija, šāds regulējums ne visās situācijās atviegloja personas pieeju tiesas aizsardzībai un neatbilda mērḳim, kādu likumdevējs bija izvirzījis, to pieṇemot.

Reageèjot uz iepriekš izklāstīto situāciju, 2020. gada 8. septembrī tika iesniegti priekšlikumi likumprojektā "Grozījumi Civilprocesa likumā” (Nr. 554/Lp13), kurš tika izskatīts Saeimas Juridiskajā komisijā pirms trešā lasījuma. Priekšlikumi

${ }^{19}$ Ministru kabineta 25.03.2014. noteikumu Nr. 161 "Kārtība, kādā novērš vardarbības draudus un nodrošina pagaidu aizsardzibu pret vardarbïbu" $9 .{ }^{1}$ punkts.

${ }^{20}$ Ministru kabineta 28.07.2020. noteikumu Nr. 462 anotācija. Pieejams: http://tap.mk.gov.lv/doc/2020_07/ IEMAnot_150620_161.1205.docx [aplūkots 09.03.2021.].

21 Augstākās tiesas Krimināllietu departamenta 23.03.2016. lēmums lietā Nr. SKK-122/2016. Pieejams: at.gov.lv [aplūkots 09.03.2021.].

22 "Es tev atņemšu dārgāko." Lai atriebtos sievai, varmāka nožņaudz meitu. Pieejams: https://rebaltica.lv/2020/09/es-tev-atnemsu-dargako-lai-atriebtos-sievai-varmaka-noznaudz-meitu/ [aplūkots 09.03.2021.].

${ }^{23}$ Civilprocesa likuma $250 .{ }^{55}$ panta trešā daḷa, $250 .{ }^{56}$ panta trešā daḷa [01.07.2019. red.].

24 Par priekšlikumiem likumprojektam "Grozijumi Civilprocesa likumā" (Nr. 554/Lp13). Pieejams: https:/titania.saeima.lv/LIVS13/saeimalivs13.nsf/0/773C60217FBFDBE1C22585DD0047B3CE?Open Document [aplūkots 09.03.2021.]. 
paredzēja, ka pieteikumu par pagaidu aizsardzību pret vardarbïbu pirms prasības celšanas var iesniegt tiesai ne tikai pēc aizskāruma nodarīšanas vietas, bet arī pēc pieteicēja atrašanās vietas, tādējādi sniedzot personai iespēju lūgumu nodrošināt aizsardzību iesniegt jebkurā tiesā Latvijā, lai kur arī vardarbỉbas upuris tobrīd būtu spiests atrasties. ${ }^{25}$

Priekšlikumus vienbalsīgi atbalstīja gan Juridiskās komisijas deputāti, gan Tieslietu ministrija. Saeimas Juridiskais birojs norādīja, ka, lai gan priekšlikumi iesniegti pirms trešā lasijuma (parlamentārajā praksē nostiprinājies princips, ka iesniegt saturiski jaunus priekšlikumus pirms likumprojekta trešā, galīgā lasijuma nav vēlams), šajā gadījumā nav saskatāmi šḳērṣ̌li to atbalstīšanai, nosakot attiecīgo piekritību personas dzīvības un veselības aizsardzības interesēs. ${ }^{26}$

Grozìjumi Civilprocesa likumā stājās spēkā 2021. gada 1. janvārī, cita starpā paredzot, ka turpmāk pieteikumu par pagaidu aizsardzību pret vardarbību pirms prasības celšanas varēs iesniegt gan pēc aizskāruma nodarīšanas vietas, gan pēc pieteicēja atrašanās vietas. ${ }^{27}$ Tādējādi šobrìd Civilprocesa likums attiecībā uz pieteikumu par pagaidu aizsardzibu pret vardarbibu pirms prasības celšanas būtībā paredz piekritību pēc prasîtāja izvēles, jo prasitājs var izvēlēties, kurā tiesā iesniegt prasibu.

\section{Sociālās rehabilitācijas kurss vardarbīgas uzvedības mazināšanai kā jauns pagaidu aizsardzỉbas pret vardarbibu liddzeklis}

Pagaidu aizsardzības pret vardarbību institūta būtiska sastāvdaḷa ir Civilprocesa likuma $250 .{ }^{47}$ panta pirmajā daļā nostiprinātais konkrētu līdzekḷu uzskaitījums, ar kuru tiesa var noteikt iespējami efektīvāko personas tiesību aizsardzību. Turklāt līdzekḷu saraksts nav izsmel̦ošs un tiesa var noteikt arī citus aizliegumus un pienākumus, kas šajā panta dạ̦ā nav minēti. ${ }^{28}$

N̦emot vērā valsts pienākumu veikt preventīvus pasākumus vardarbības mazināšanai, tieslietu ministrs 2020. gadā Saeimā izskatāmajam likumprojektam "Grozïjumi Civilprocesa likumā” (Nr. 599/Lp13) pirms otrā lasījuma iesniedza priekšlikumu paplašināt Civilprocesa likuma $250 .{ }^{47}$ pantā noteikto pagaidu aizsardzības pret vardarbību līdzekḷu klāstu, ieviešot iespēju tiesai uzlikt par pienākumu atbildētājam iziet sociālas rehabilitācijas kursu vardarbīgas uzvedības mazināšanai, lai novērstu vai mazinātu turpmākus vardarbības riskus. ${ }^{29}$ Savukārt 2021. gada 25. martā Saeima atbalstīja iepriekš minēto likumprojektu trešajā lasījumā un lēma, ka tiesiskais regulējums attiecībā uz pagaidu aizsardzības pret vardarbību

${ }^{25}$ Par priekšlikumiem likumprojektam “Grozījumi Civilprocesa likumā” (Nr. 554/Lp13). Pieejams: https:// titania.saeima.lv/LIVS13/saeimalivs13.nsf/0/773C60217FBFDBE1C22585DD0047B3CE?OpenDocume nt [aplūkots 09.03.2021.].

${ }^{26}$ Saeimas Juridiskās komisijas 16.09.2020. sēdes protokols. Pieejams: http://titania.saeima.lv/livs/saeimasnotikumi.nsf/0/3d153ed2c23e0ae7c22585df00238862/\$FILE/PR_2020_09_16_10_00_JK.002.pdf/ PR_2020_09_16_10_00_JK.pdf [aplūkots 09.03.2021.].

27 Grozijumi Civilprocesa likumā: LV likums. Pieņemts: 01.10.2020. [09.03.2021. red.].

${ }^{28}$ Civilprocesa likuma $250 .{ }^{47}$ panta pirmās daḷas 8. punkts.

${ }^{29}$ Par priekšlikumiem likumprojektam “Grozijumi Civilprocesa likumā” (reg̀. Nr. 599/Lp13) pirms otrā lasijuma. Pieejams: https://titania.saeima.lv/LIVS13/SaeimaLIVS13.nsf/0/7E5AC1558B6733C2C2258582 003CD1D6?OpenDocument [aplūkots 09.03.2021.]. 
līdzekli - pienākumu apgūt sociālās rehabilitācijas kursu - stāsies spēkā 2021. gada 1. jūlijā..$^{30}$

Atbilstoši Ministru kabineta 2014. gada 23. decembra noteikumiem Nr. 790 "Sociālās rehabilitācijas pakalpojumu sniegšanas kārtība no vardarbības cietušām un vardarbību veikušām pilngadīgām personām" ${ }^{11}$ vardarbību veikušās personas kopš 2015. gada 1. janvāra var saņemt no valsts budžeta līdzekḷiem finansētus sociālās rehabilitācijas pasākumus. Iepriekš minētie Ministru kabineta noteikumi līdz šim balstijiušies uz brīvprātības principu - persona var brīvprātīgi pieteikties un, ja viṇa atbilst noteikumos izvirzìtajiem kritērijiem, saṇemt valsts apmaksātu vardarbīgas uzvedības mazināšanas pakalpojumu. ${ }^{32}$ Taču, kā pareizi norādījusi biedrības "Centrs Marta" vadītāja Iluta Lāce, varmākas brīvprātīgi reti kad dodas uz šādām nodarbībām un viṇi ir jāmudina to darīt. ${ }^{33}$ Tādējādi jānorāda, ka tiesas iespējas uzlikt par pienākumu iziet sociālās rehabilitācijas kursu vardarbīgas uzvedības mazināšanai iekḷaušana piemērojamo pagaidu aizsardzības pret vardarbību līdzekḷu klāstā turpmāk būs būtisks solis, lai preventivi iedarbotos uz personu un mazinātu noziedzīgas uzvedības iespēju. ${ }^{34}$

Būtiski atzīmēt, ka līdz ar grozìjumu apstiprināšanu galīgajā lasijumā tika atbalstīti vēl vairāki nozīmīgi priekšlikumi. Piemēram, par sociālā rehabilitācijas kursa finansēšanas kārtību, proti, vardarbīgajai personai būs pienākums ar līdzmaksājumu dạ̦ēji segt kursa izmaksas. Ja persona sāks apgūt kursu sešu mēnešu laikā pēc tiesas lēmuma saņemšanas, tad tai būs jāsedz kursa izmaksas desmit procentu apmērā, taču, ja kursa apgūšana tiks uzsākta vēlāk, izmaksas būs jāsedz pilnā apmērā. Saprotams, ka atbildētāja finanšu trūkumam nevajadzētu būt par šķērsli apgūt sociālās rehabilitācijas kursu, taču reizē ir nepieciešams arī motivēt personu apgūt kursu pēc iespējas ātrāk. Tāpat tiesai turpmāk būs rīcības brīvība lemt par šãdu pagaidu aizsardzības līdzekli arī pēc savas iniciatīvas, pat ja prasitājs to nav lūdzis piemērot. Turklāt jāatzīmēe, ka likumā paredzēta arī atbildība par kursa laicīgu neapgūšanu, kas reizē ir efektīvs instruments atbildētāja motivēšanai kursu apgūt pēc iespējas ātrāk. Proti, ja gada laikā sociālās rehabilitācijas kurss vardarbīgas uzvedības mazināšanai netiks apgūts, atbildētājs būs atbildīgs saskaṇā ar Krimināllikumu. ${ }^{35}$

Jaunais pagaidu aizsardzības pret vardarbību līdzeklis nenoliedzami būs efektîvs instruments, lai preventivi iedarbotos uz vardarbīgo personu, samazinot atkārtotas vardarbïbas gadījumus.

30 Sk. likumprojekta “Grozijumi Civilprocesa likumā” (reg. Nr. 599/Lp13) tabulu. Pieejams: https:// titania.saeima.lv/LIVS13/SaeimaLIVS13.nsf/webAll?SearchView\&Query $=([$ NumberTxt $]=599 /$ Lp13 $) \&$ SearchMax=0\&SearchOrder=4 [aplūkots 09.03.2021.].

31 Sociālās rehabilitācijas pakalpojumu sniegšanas kārtība no vardarbības cietušām un vardarbību veikušām pilngadīgām personām: Ministru kabineta noteikumi. Pieņemts: 23.12.2014. [09.03.2021. red.].

32 Par priekšlikumiem likumprojektam “Grozijumi Civilprocesa likumā” (reǵ. Nr. 599/Lp13) pirms otrā lasījuma. Pieejams: https://titania.saeima.lv/LIVS13/SaeimaLIVS13.nsf/0/7E5AC1558B6733C2C2258582 003CD1D6?OpenDocument [aplūkots 09.03.2021.].

${ }^{33}$ Mudina ğimenes varmākām likt iziet obligātu rehabilitāciju. Pieejams: https://nra.lv/latvija/kriminalzinas/ 265335-mudina-gimenes-varmakam-likt-iziet-obligatu-rehabilitaciju.htm [aplūkots 09.03.2021.].

34 Par priekšlikumiem likumprojektam “Grozïjumi Civilprocesa likumā” (reg̣. Nr. 599/Lp13) pirms otrā lasijuma. Pieejams: https://titania.saeima.lv/LIVS13/SaeimaLIVS13.nsf/0/7E5AC1558B6733C2C2258582 003CD1D6?OpenDocument [aplūkots 09.03.2021.].

35 Sk. 30., 31. un 35. priekšlikumu. Priekšlikumu tabula likumprojektam "Grozïjumi Civilprocesa likumā" (reg. Nr. 599/Lp13) trešajam lasījumam Saeimas sēdē. Pieejams: https://titania.saeima.lv/LIVS13/saeimalivs13.nsf/0/6E2D71035B880F3AC2258695004EDD6F?OpenDocument [aplūkots 15.03.2021.]. 


\section{Kopsavilkums}

1. Ar civilprocesuālā institūta - pagaidu aizsardzības pret vardarbību - ieviešanu Latvijas normatīvajā regulējumā ir sperts nozīmīgs solis, lai vardarbībā cietušo personu tiesības tiktu tūlīeēji un efektīivi aizsargātas pret turpmāku vardarbības apdraudējumu.

2. Kaut arī pagaidu aizsardzība pret vardarbību ir būtisks institūts vardarbībā cietušo aizsardzībai un praksē ir pierādījies kā gana efektīvs instruments, vardarbỉba, it īpaši vardarbỉba gimenē, joprojām ir aktuāla problēma Latvijas sabiedrībā, tādēl arvien ir jāstrādā arī pie tiesiskā regulējuma uzlabošanas.

3. Pēdējā gada laikā, aktualizējoties vairākām pagaidu aizsardzības pret vardarbību regulējuma piemērošanas problēmām, ir panākti būtiski uzlabojumi šì institūta tiesiskajā kārtībā.

4. Stājoties spēkā grozījumiem Civilprocesa likumā, no 2021. gada 1. janvāra vardarbībā cietusī persona var iesniegt pieteikumu par pagaidu aizsardzību pret vardarbību ne tikai tiesā pēc aizskāruma nodarīšanas vietas, bet arī jebkurā tiesā pēc savas atrašanās vietas, kas noteiktās situācijās ir izšķiroši, lai atvieglotu personas pieeju tiesai un ātri un efektīvi aizsargātu personas tiesības.

5. Lat vijas Republikas Saeima 2021. gada 25. martā pieņēma grozījumus Civilprocesa likumā, kas stāsies spēkā 2021. gada 1. jūlijā un ieviesīs jaunu pagaidu aizsardzības pret vardarbību līdzekli - sociālās rehabilitācijas kursa apgūšanu vardarbīgas uzvedības mazināšanai. Lìdz grozịjumu spēkā stāšanās brīdim dalība sociālās rehabilitācijas pasākumos ir brīvprātīga iespēja vardarbīgām personām, taču pēc 2021. gada 1. jūlija tiesa kursa apgūšanu varēs noteikt kā obligātu pienākumu. Turklāt atbildētājam būs pienākums dậ̄ji segt kursa izmaksas desmit procentu apmērā, ja atbildētājs uzsāks apgūt kursu sešu mēnešu laikā, bet pilnā apmērā, ja atbildētājs uzsāks apgūt kursu pēc sešiem mēnešiem. Tādējādi tiks ieviests jauns preventīvs līdzeklis, kā mazināt vardarbības situāciju iespējamo atkārtošanos nākotnē. 